\title{
Characterization of Female External Genitalia and Eggs of Four South American Species of the Triatoma Laporte, 1832 Genus (Hemiptera: Reduviidae: Triatominae)
}

\author{
Tiago Belintani $^{1}{ }^{(D)}$, Jader Oliveira ${ }^{2} \mathbb{D}$, Heloisa Pinotti ${ }^{3}$, Kaio Cesar Chaboli Alevi ${ }^{3}$, Juliana Damieli Nascimento ${ }^{1}$, \\ Estela Sasso-Cerri ${ }^{4}$, Cleber Galvão ${ }^{5, *(D)}$ and João Aristeu da Rosa ${ }^{3}$ \\ 1 Institute of Biology, Campinas State University (Unicamp), Block O, Bertrand Russel Avenue, \\ Campinas 13083-865, São Paulo, Brazil; tiagobellintani@gmail.com (T.B.); judamieli@gmail.com (J.D.N.) \\ 2 Laboratory of Entomology in Public Health, Department of Epidemiology, Faculty of Public Health, \\ University of São Paulo, Av. Arnaldo 01246-904, São Paulo, Brazil; jdr.oliveira@hotmail.com \\ 3 School of Pharmaceutical Sciences, São Paulo State University (Unesp), Araraquara-Jaú Highway, km 1, \\ Campos Ville, Araraquara 14800-903, São Paulo, Brazil; helopinotti@hotmail.com (H.P.); \\ kaiochaboli@hotmail.com (K.C.C.A.); joaoaristeu@gmail.com (J.A.d.R.) \\ 4 Department of Morphology, Genetics, Orthodontics and Pediatric Dentistry, Dental School, \\ São Paulo State University (Unesp), Rua Humaitá, 1680, Araraquara 14801-903, São Paulo, Brazil; \\ estela.sasso@unesp.br \\ check for \\ updates \\ Citation: Belintani, T.; Oliveira, J.; \\ 5 National and International Reference Laboratory in Taxonomy of Triatomines, Oswaldo Cruz Institute, \\ Fiocruz, Av. Brasil, 4365, Manguinhos 21040-360, Rio de Janeiro, Brazil \\ * Correspondence: clebergalvao@gmail.com
} Pinotti, H.; Alevi, K.C.C.; Nascimento, J.D.; Sasso-Cerri, E.; Galvão, C.; Aristeu da Rosa, J. Characterization of Female External Genitalia and Eggs of Four South American Species of the Triatoma Laporte, 1832 Genus (Hemiptera: Reduviidae: Triatominae). Insects 2021, 12, 537 https://doi.org/10.3390/ insects12060537

Academic Editor: Robert M. Waterhouse

Received: 4 March 2021

Accepted: 9 April 2021

Published: 10 June 2021

Publisher's Note: MDPI stays neutral with regard to jurisdictional claims in published maps and institutional affiliations.

Copyright: () 2021 by the authors. Licensee MDPI, Basel, Switzerland. This article is an open access article distributed under the terms and conditions of the Creative Commons Attribution (CC BY) license (https:// creativecommons.org/licenses/by/ $4.0 /)$.
Simple Summary: We present a morphological and morphometric study with T. garciabesi, T. guasayana, T. patagonica, and T. sordida sensu stricto species within the Triatoma genus. This group of species is important for the eco-epidemic scenario of Chagas disease in the Americas; their species have morphological, biological, and behavioral similarities that make diagnosis difficult. For the first time, the description of the female external genitalia by scanning electron microscopy (SEM), a character that has helped with the delimitation of species and genera in Triatominae, is published, in addition to presenting an extensive study with eggs, covering morphology and morphometry. The study with eggs is an important tool in taxonomic studies of the subfamily. In addition to taxonomic contributions, it was possible through the descriptions to corroborate the validity of T. garciabesi and confirm the current classification of these species.

Abstract: Triatoma is the most diversified and one of the most important genera from an epidemiological perspective. Given the difficulty in identifying some species of the Triatoma genus, morphological, histological, and morphometric studies were performed to provide new characters that make it possible to differentiate T. garciabesi, T. guasayana, T. patagonica, and T. sordida sensu stricto, triatomines that overlap geographically and have vector potential. Through the external female genitalia, as well as morphology, morphometry, and histology of eggshells, it was possible to discriminate the four species. In addition, this study reinforces the taxonomic validity of $T$. garciabesi and provides new data for discussion on systematic issues of T. guasayana and T. patagonica.

Keywords: Triatominae; Triatoma; morphology; morphometry; Chagas diseases

\section{Introduction}

Chagas disease vectors belong to the subfamily Triatominae, which includes 156 extant and three fossil species [1-3]. Triatomines occur mainly in the Americas, with few exceptions outside the continent [4]. Among the genera of Triatominae, Triatoma Laporte, 1832 , is the most representative in species and relevant to the eco-epidemiological scenario of Chagas infection [5]. The diversity in Triatoma reflects in inconclusive phylogenies, the 
genus has at least two paraphyletic groups [6]. In addition to the systematic problems inherent to Triatoma, phylogenies with the Tribe Triatomini, recover unnatural groups [6], condition that keeps the discussion about the evolutionary origin of the group [4]. However, the integration of genetic and phenetic characters has helped to elucidate the evolutionary history of the group, but new revisions are necessary $[4,7,8]$. There are also systematic problems in the organization of complexes and subcomplexes of Triatoma [8]. Morphological, biological and behavioral similarities are common in the genus, as in the species Triatoma garciabesi Carcavallo, et al. 1967; Triatoma guasayana Wygodzinsky and Abalos, 1949; Triatoma patagonica Del Ponte, 1929, and Triatoma sordida (Stål, 1859) evaluated in this study.

Traditionally, the four species mentioned above formed the T. sordida subcomplex proposed by Schofield and Galvão [9]. Currently, after the proposed reorganization by means of chromosomal deposition of the main ribosomal DNA (rDNA) [8] the species T. garciabesi, T. sordida sensu stricto and Triatoma rosai Alevi et al. [3] (T. rosai recently described was for a period considered a polymorphic population of T. sordida with distribution in Argentina) remain in the T. sordida subcomplex, while T. guasayana and T. patagonica were transferred in the T. rubrovaria subcomplex. The new organization was corroborated by phylogenetic study with genetic and morphometric markers [7].

These triatomines have morphological and behavioral similarities, in addition, they overlap in some geographic ranges with reports of hybrid specimens [10]. The four species are currently restricted to South America, $T$. sordida sensu stricto has a wide geographical distribution and can be found in Argentina, Bolivia, Brazil, and Paraguay, T. garciabesi and T. patagonica are restricted to Argentina, while T. guasayana occurs in Argentina, Bolivia, and Paraguay $[5,11,12]$.

Triatoma garciabesi is very similar to T. sordida, evident in the morphological, behavioral, and biogeographic similarities [6,13]. The dignity of T. garciabesi is complex and errors in identification are frequent [11]. Triatoma guasayana has morphological similarity to T. sordida, mainly in the early stages of development [14,15], however morphometric, cytogenetics and phylogenetic studies support the taxa as distinct $[7,11,16]$. Triatoma patagonica is distributed in the Southern most region of South America, this naturally wild triatomine has epidemiological relevance and can inhabit artificial environments, such as chicken coops and pens [12]. The species shows greater morphological differences $[11,16,17]$ and genetic differences $[7,18,19]$ in relation to T. garciabesi, T. guasayana, and T. sordida.

Initially described as Conorhinus sordidus (Stål, 1859), Triatoma sordida is widely distributed in South American countries [11,18]. Forattini [20] suggests that the species has focus of endemism in the central region of Brazil. The author discusses the preference and tolerance for high temperatures and dry climates, a relevant factor for dispersal of the species. Studies with T. sordida sensu stricto show enzymatic, genetic [5,11,21], morphological and morphometric diversity $[5,16,22]$. The first record of T. sodida variability goes back to 1951 [14]. However, the Brazilian populations of T. sordida sensu stricto have little genetic variability [23-25]. The terminology used in this study for T. sordida sensu stricto refers to the suggestion of Panzera et al. [11], the term describes species distributed throughout Brazil, central Paraguay, Chaco, and eastern Bolivia.

Due to the importance of correct vector identification, this study evaluates morphological and morphometric characters that group and distinguish T. garciabesi, T. guasayana, T. patagonica, and T. sordida sensu stricto. In addition, we present two new characters for the studied species, the female external genitalia, and the histological profile of the exochoria.

\section{Materials and Methods}

\subsection{Taxon Sampling}

The specimens used in this work were obtained from the Triatominae Insectary of São Paulo State University Julio de Mesquita Filho, School of Pharmaceutical Sciences, Araraquara, São Paulo, Brazil (https:/ / www2.fcfar.unesp.br/\#!/triatominae accessed on 1 January 2021) accessed on 10 October 2020 and from the Triatomine Collection of the 
Oswaldo Cruz Institute (http:/ / ctioc.fiocruz.br/ accessed on 1 January 2021) accessed on October 2020. The specimens were identified from descriptions and identification keys $[13,17]$. In this study we used: T. garciabesi (Rivadavia, Province of Medonça, Argentina), T. guasayana (Cochabamba, Department of Cochabamba), T. patagonica (Jachal, Province of San Juan, Argentina), and T. sordida sensu stricto (Seabra, State of Bahia, Brazil) (Figure 1).
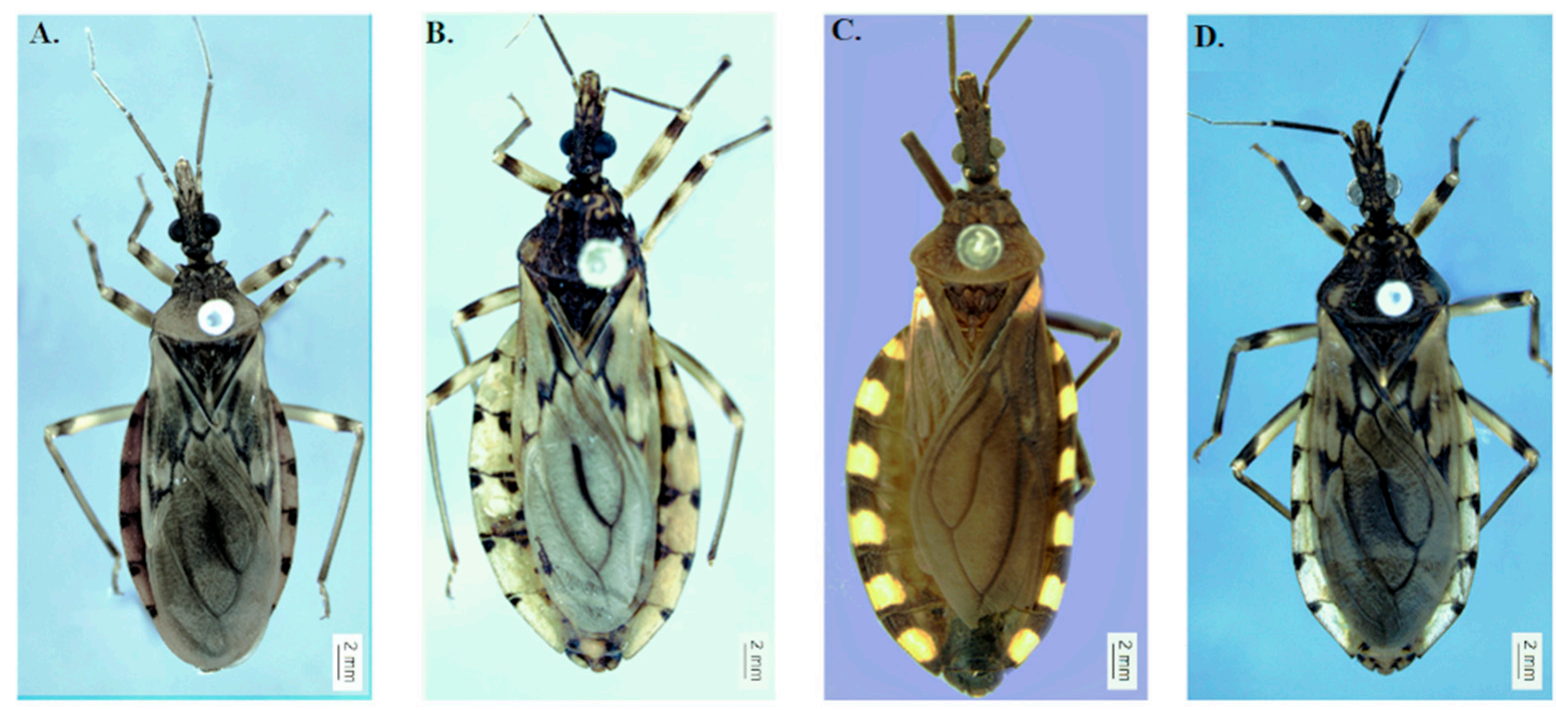

Figure 1. Species analyzed in this study. (A) T. garciabesi, (B) T. guasayana, (C) T. patagonica, and (D) T. sordida sensu stricto.

\subsection{Morphological Studies}

2.2.1. Morphologic Study of External Female Genitalia and Eggshells

The images female external genitalia $(n=5)$ and the eggshells $(n=5)$ of the four species were produced by scanning electron microscopy (SEM) according to Rosa et al. [25]. After death by freezing in $-20^{\circ} \mathrm{C}$, the specimens were dissected from the sixth segment to acquire the final portion of the abdomen, with the female external genitalia. Subsequently, the dissected structures were washed, dehydrated with an alcohol series, and oven dried for $30 \mathrm{~min}$ at $50^{\circ} \mathrm{C}$. The female external genitalia were examined in the dorsally, posteriorly, and ventrally. The eggshells were also subjected to washing, dehydration, and drying. Subsequently, they were fixed on aluminum stubs. The samples of the female external genitalia and the eggshells were by sputtering with gold for $2 \mathrm{~min}$ at $10 \mathrm{~mA}$, as described in Rosa et al. [25]. Subsequently, the female external genitalia (dorsal, posterior, and ventral views) and the eggshells (full and exochorion aspect) were examined with a Topcon SM 300 SEM at the Institute of Chemistry at Unesp, Araraquara, São Paulo, Brazil. The images obtained were processed (background, contrast, brightness) in the GNU Image Manipulation Program v2.0.2 (GIMP) software free and open-source image editor, subsequently the structures were described, and the descriptions were compared.

\subsubsection{Histological Analysis}

The eggshell histological procedures were conducted at the Laboratory of Histological Processing of the Dental School, Unesp, Araraquara, São Paulo, Brazil following a protocol adapted from Obara et al. [26]. Five hatched eggs of each species were selected, and the shells were washed in acetone using ultrasound ( $40 \mathrm{kHz}$ for $3 \mathrm{~min}$ ) and dried at $40{ }^{\circ} \mathrm{C}$ for $30 \mathrm{~min}$. The eggshells were transferred to small plastic cassettes and submitted to histological processing in a "MORSE" descaling solution (formic acid + sodium citrate) for $15 \mathrm{~min}$. With the aid of a scalpel, the shells were split in half under a surgical magnifying glass. The fragments were washed in running water for $1 \mathrm{~h}$, dehydrated in a graded ethanol series $(2 \mathrm{~h})$, diaphanized in xylene for $1 \mathrm{~h}$, and embedded in liquid paraffin at $60^{\circ} \mathrm{C}(2 \mathrm{~h})$. 
Subsequently, the samples were cut with a LEICA RM $2145^{\circledR}$ microtome, and $5 \mu \mathrm{m}$-thick sections were stained with Harris' Hematoxylin (10 min) and Eosin (5 min). The stained sections were mounted with Permount mounting medium and observed under a Leica microscope (c) Leitz DM RXE with a digital camera.

\subsection{Morphometric Study}

Morphometric Analysis of Eggshells

The total length and perimeter of the opercular opening of the eggs were measured based on classical morphometric methods [27,28]. For eggshell morphometry, 50 eggs were selected from T. garciabesi, T. guasayana, T. patagonica, and T. sordida sensu stricto. Variations were estimated by ANOVA and Tukey's post-hoc test $(p<0.05 \%)$ and were computed using GraphPad Prism (Graphpad Software v. 8.00 for Windows, San Diego, CA, USA).

\section{Results}

\subsection{Morphological Analyses}

\subsubsection{Female External Genitália}

The female external genitalia of T. garciabesi, T. guasayana, T. patagonica, and T. sordida sensu stricto are described for the first time. Among the species studied, the female external genitals have different characters in the three positions evaluated (dorsal, ventral, and posterior), allowing specific identification. The main differences in female external genitalia are compiled in Table 1.

Table 1. Comparative morphology of the female external genitalia of T. garciabesi, T. guasayana, T. patagonica, and T. sordida sensu stricto in dorsal, posterior, and ventral view.

\begin{tabular}{|c|c|c|c|c|c|c|c|c|}
\hline & & Dorsal & & & & Posterior & Ventral & \\
\hline Species & $\begin{array}{c}\text { The Shape } \\
\text { of VII }\end{array}$ & $\begin{array}{c}\text { The Shape } \\
\text { of VIII }\end{array}$ & $\begin{array}{c}\text { The Shape } \\
\text { of IX }\end{array}$ & $\begin{array}{c}\text { The } \\
\text { Shape } \\
\text { of X }\end{array}$ & $\begin{array}{c}\text { The Shape } \\
\text { of VIII }\end{array}$ & $\begin{array}{c}\text { The Shape } \\
\text { of X }\end{array}$ & $\begin{array}{l}\text { Posterior } \\
\text { Portions of the } \\
\text { Connexiva of } \\
\text { the VII }\end{array}$ & $\begin{array}{c}\text { The Lines } \\
\text { That Divide } \\
\text { the Seg- } \\
\text { ments VIII } \\
\text { and IX }\end{array}$ \\
\hline T. garciabesi & $\begin{array}{l}\text { straight lines, } \\
\text { trapezoidal }\end{array}$ & trapezoidal & $\begin{array}{l}\text { trapezoidal } \\
\text { more evident }\end{array}$ & obtuse & $\begin{array}{l}\text { VIII and IX } \\
\text { segments are } \\
\text { convex }\end{array}$ & semicircular & $\begin{array}{l}\text { VII segment end } \\
\text { in pointed tips }\end{array}$ & convex \\
\hline T. guasayana & $\begin{array}{c}\text { Straight } \\
\text { lines, } \\
\text { trapezoidal }\end{array}$ & trapezoidal & trapezoidal & obtuse & $\begin{array}{c}\text { VIII and IX } \\
\text { segments are } \\
\text { flat }\end{array}$ & flat & $\begin{array}{l}\text { VII segment end } \\
\text { in rounded tips }\end{array}$ & Flat \\
\hline T. patagonica & $\begin{array}{l}\text { curved lines, } \\
\text { trapezoidal }\end{array}$ & trapezoidal & trapezoidal & flat & $\begin{array}{c}\text { VIII and IX } \\
\text { segments are } \\
\text { convex }\end{array}$ & $\begin{array}{l}\text { Semicircular, } \\
\text { curved } \\
\text { elongated }\end{array}$ & $\begin{array}{l}\text { VII segment end } \\
\text { in pointed tips }\end{array}$ & Convex \\
\hline $\begin{array}{c}\text { T. sor- } \\
\text { dida sensu stricto }\end{array}$ & $\begin{array}{c}\text { curved lines, } \\
\text { trapezoidal }\end{array}$ & trapezoidal & $\begin{array}{l}\text { trapezoidal } \\
\text { more evident }\end{array}$ & obtuse & $\begin{array}{l}\text { VIII and IX } \\
\text { segments are } \\
\text { flat }\end{array}$ & Semicircular & $\begin{array}{l}\text { VII segment end } \\
\text { in rounded tips }\end{array}$ & flat \\
\hline
\end{tabular}

\subsubsection{Dorsal View of Female External Genitalia}

The borders (with a pair) between the segment VII and the connective are straight in T. garciabesi and T. guasayana (Figure 2A,B), in T. patagonica and T. sordida sensu stricto the lower portion is slightly curved (Figure $2 \mathrm{C}, \mathrm{D}$ ).

Posterior portions (with a pair) of the VII segment at the limit with the VIII segment and connexiva end as triangular tips in T. garciabesi, T. guasayana, T. patagonica, and T. sordida sensu stricto (Figure 2). The VIII segment has a trapezoid shape in the four species, in T. guasayana the lower part is curved in the others the angles are straight.

Segment IX has a trapezoidal shape in the four species, but in T. guasayana the region is lower and wider (Figure 2E-H) in, T. patagonica is slightly curved on the sides (Figure 3). Posterior portions (with a pair) of the IX segment in T. guasayana have the shape of rounded tips (Figure 2B). The posterior portion of segment $\mathrm{X}$ is obtuse in $T$. garciabesi, $T$. guasayana and T. sordida sensu stricto and flat in T. patagonica (Figure 2). 

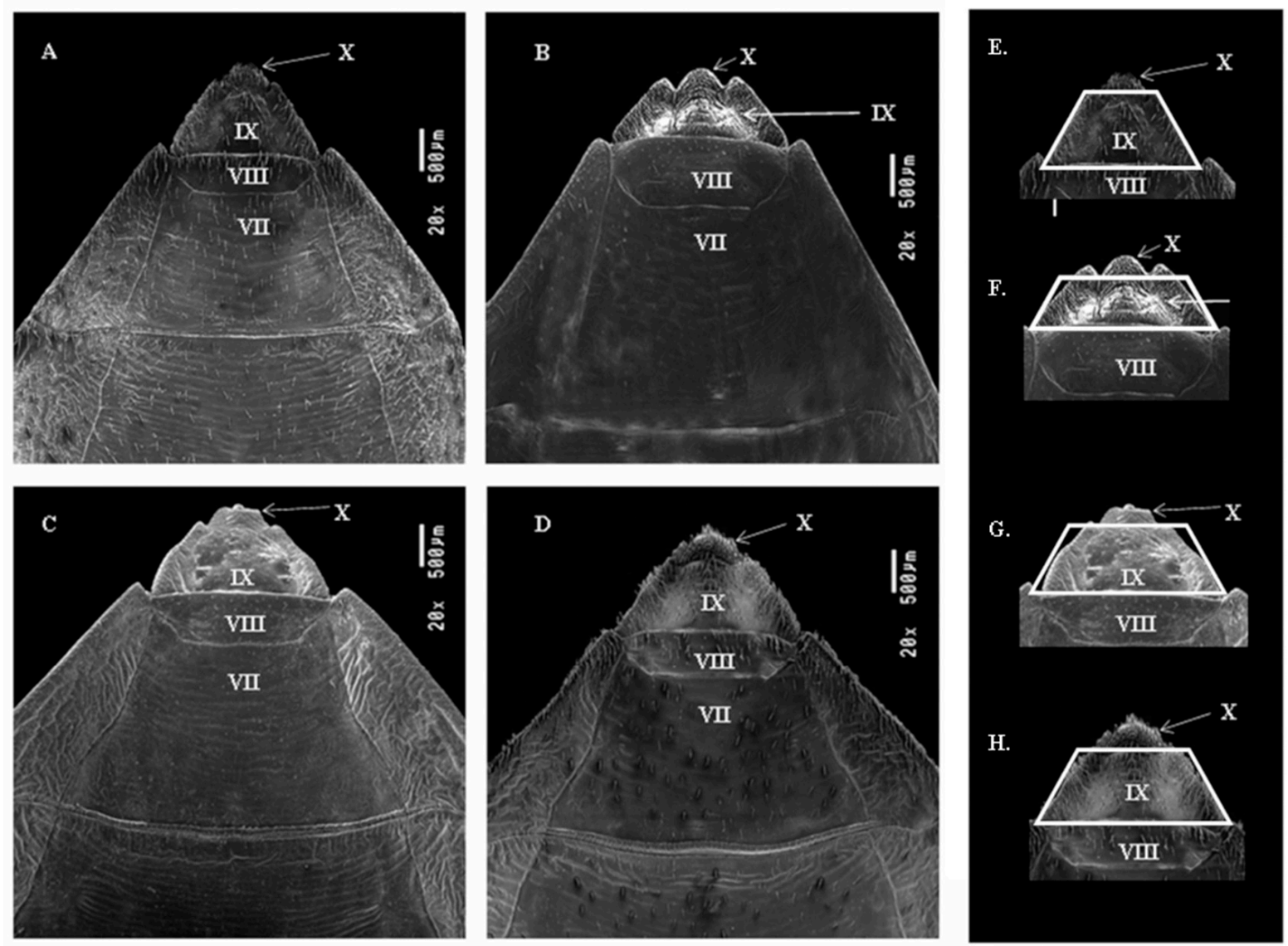

Figure 2. Dorsal view of the female external genitalia of the four species by scanning electron microscopy (SEM). (A) T. garciabesi, (B) T. guasayana, (C) T. patagonica, and (D) T. sordida sensu stricto, (E) T. garciabesi, (F) T. guasayana, (G) T. patagonica, and $(\mathbf{H})$ T. sordida stricto sensu.

\subsubsection{Posterior View of Female External Genitalia}

In T. patagonica and T. garciabesi the border of region dividing the VIII and IX segments is convex (cs) and flat in T. guasayana and T. sordida sensu stricto (Figure 3). In the four species the limits between the IX and X segments are open on the sides and closed in the central area (Figure 3); moreover, in T. patagonica the region is very curved compared to the other species. The lateral borders of the IX are curved and open close to the VIII in T. garciabesi, T. guasayana, and T. sordida sensu stricto, unlike T. patagonica that close. The $\mathrm{X}$ segment are different between species, the border between IX and X are determinant for the differences, in T. garciabesi in T. sordida sensu stricto it is semicircular (sc) in T. gasayana it is slightly flat (fs) and in T. patagonica it is considerably curved elongated (Figure 3). According to the images obtained, T. sordida sensu stricto presents a greater number of bristles in relation to the others.

\subsubsection{Ventral View of Female External Genitalia}

In the four species, the border of the VII segment with Gc8 and Gp8 is concave on the sides (with a pair) and convex in the central portion (Figure 4). Posterior portions of the connexiva of the VII segment end in pointed tips (with a pair) in T. garciabesi, T. guasayana, and T. patagonica (Figure 4A-C) in T. sordida sensu stricto is not present (Figure 4D). The Gc8 shape of T. guasayana and T. patagonica is triangular and in T. garciabesi and T. sordida sensu stricto it is triangular and obtuse. Gp9 is similar in all species, however in T. sordida sensu stricto it is smaller. (Figure 4). In T. garciabesi, T. patagonica and T. sordida sensu stricto the IX forms an isosceles triangle, while in T. patagonica the shape refers to a slightly obtuse equilateral triangle. (Figure 4B). The IX is apparent in all species: 
T. garciabesi the segment shape is triangular and well angled, T. gasayana the segment is very visible and has the obtuse final portion, $T$. patagonica the region is triangular, and the outer edges are curves, and T. sordida sensu stricto the segment is triangular with many bristles, these bristles also extend throughout the central region of VII, X, and through Gc8.
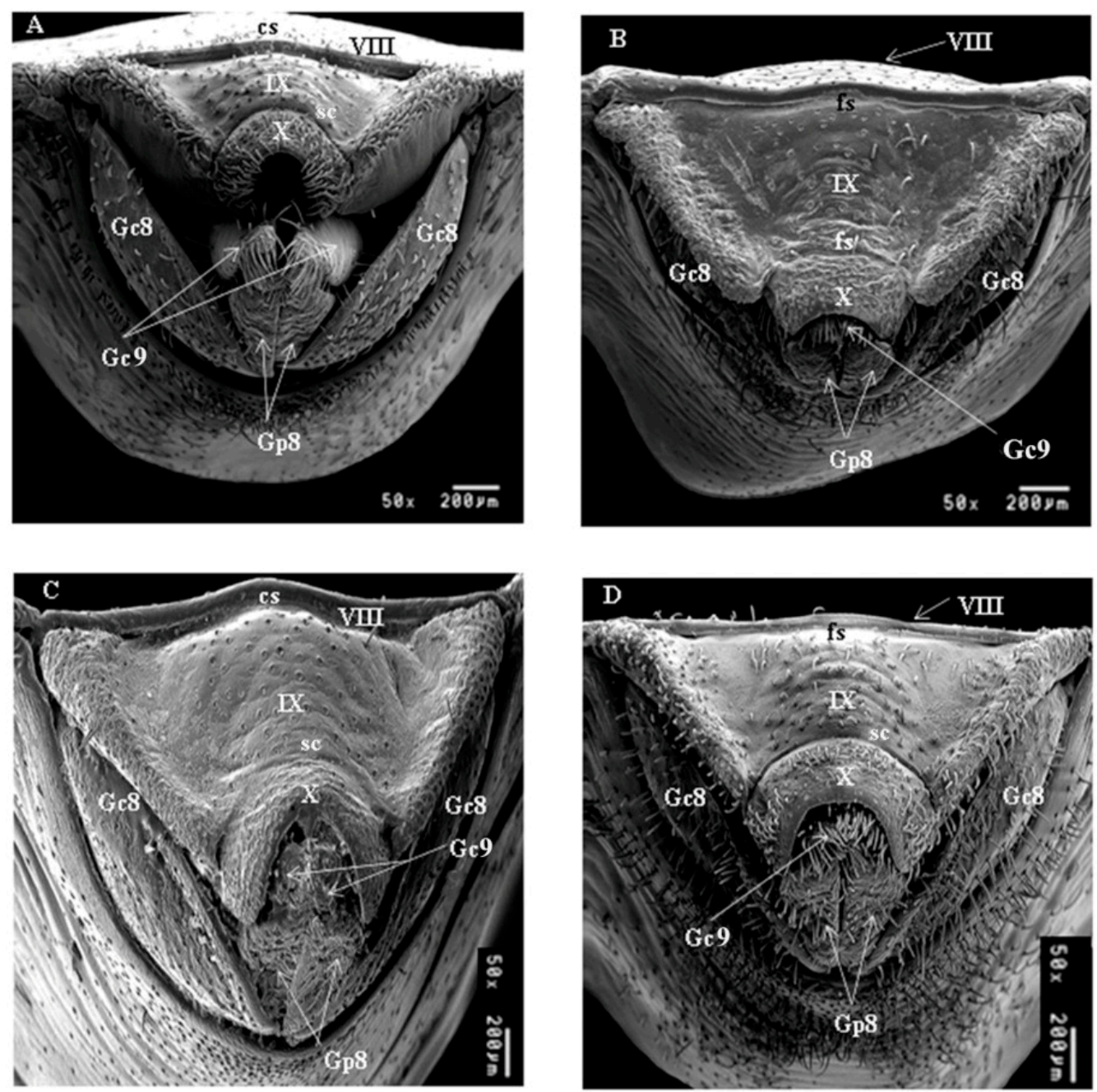

Figure 3. Posterior view of the female external genitalia of the four species by SEM. (A) T. garciabesi, (B) T. guasayana, (C) T. patagonica, and (D) T. sordida sensu stricto. Subtitles: Gc8 and Gc9: gonocoxites, 8, Gp9: gonapophyses, VII, VIII, tergite, IX, $\mathrm{X}$ segments, cs: convex shape, sc: semicircular shape and fs: flat shape.

\subsubsection{Morphology of Eggs}

Through SEM and light microscopy, it was possible to describe the architecture of the ultrastructure and the general appearance of the eggs of the four species. In general, the eggs analyzed are ellipsoidal in the four species studied (Figure 5). The four species show longitudinal chamfers that are very apparent in T. guasayana, T. patagonica, and T. sodida and less apparent in T. garciabesi (Figure 5).

The surface of exochoria in SEM is different between species. In general, the predominant shapes are pentagons, hexagons, and heptagons. In T. garciabesi, T. guasayana and T. sordida sensu stricto the shapes of the exochorion surface are varied without a defined pattern, while in T. patagonica the shapes are hexagonal. The profile of the limiting lines is different between species, it can be seen that in T. garciabesi and T. guasayana the lines are deep and define a quilted appearance for the exochorial structures, while in T. patagonica and T. sordida sensu stricto the lines are shallow and offer a flat appearance for exochorion 
(Figure 6). In the four species, numerous perforations can be observed scattered throughout the exochorion (Figure 6).
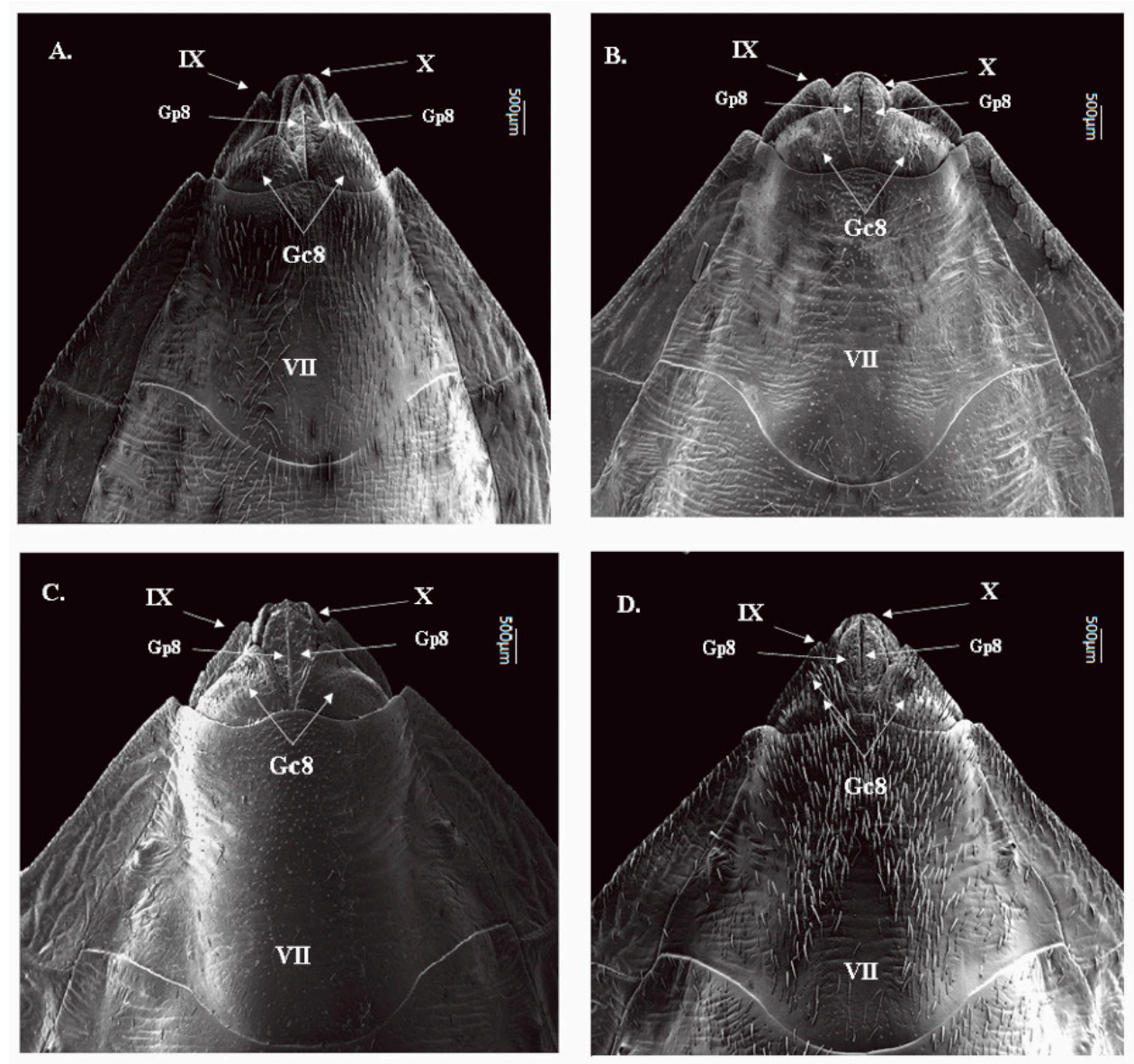

Figure 4. Ventral view of the female external genitalia of the four species by SEM. (A) T. garciabesi, (B) T. guasayana, (C) T. patagonica, and (D) T. sordida sensu stricto.

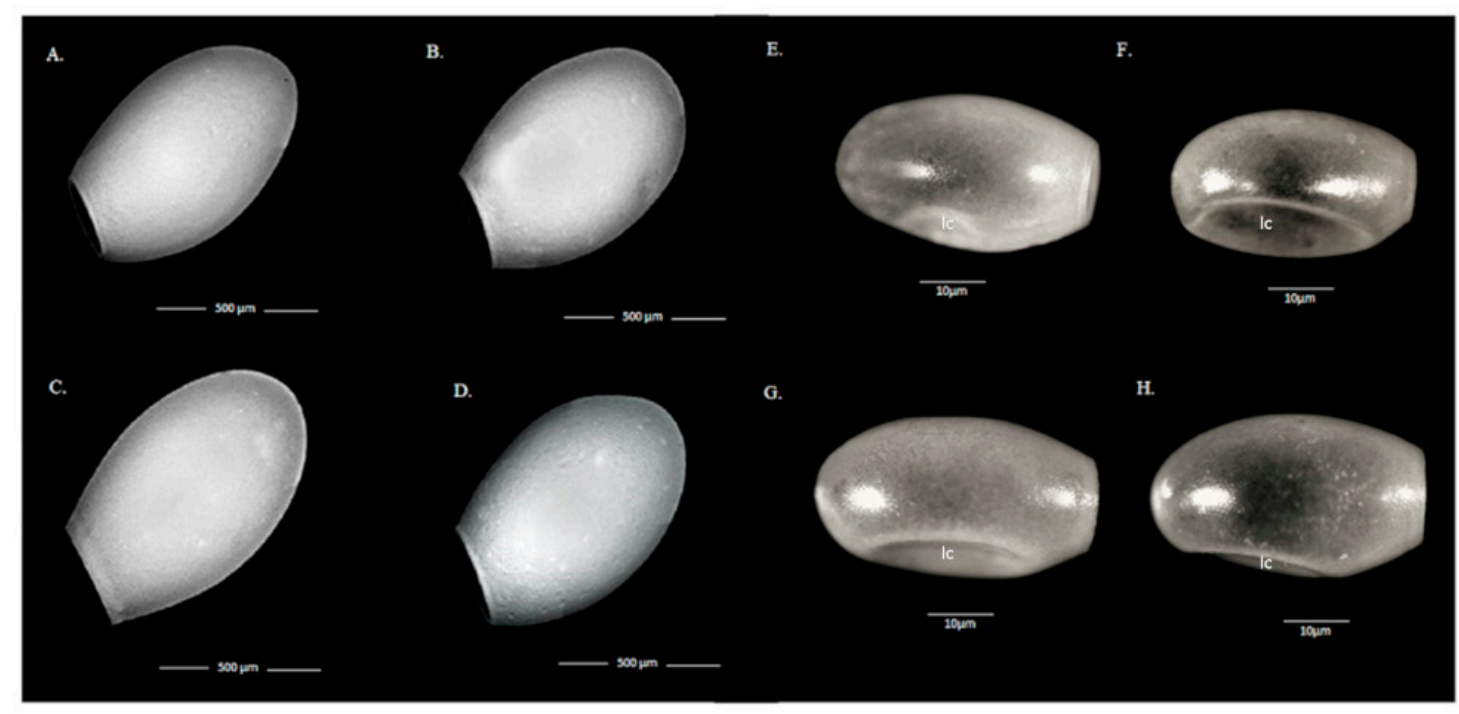

Figure 5. Eggshells' general view by scanning electron microscopy (x50) and by light microscopy (x100). (A) T. garciabesi, (B) T. guasayana, (C) T. patagonica, and (D) T. sordida sensu stricto, (E) T. garciabesi, (F) T. guasayana, (G) T. patagonica, and (H) T. sordida sensu stricto. Longitudinal chamfers (lc). 

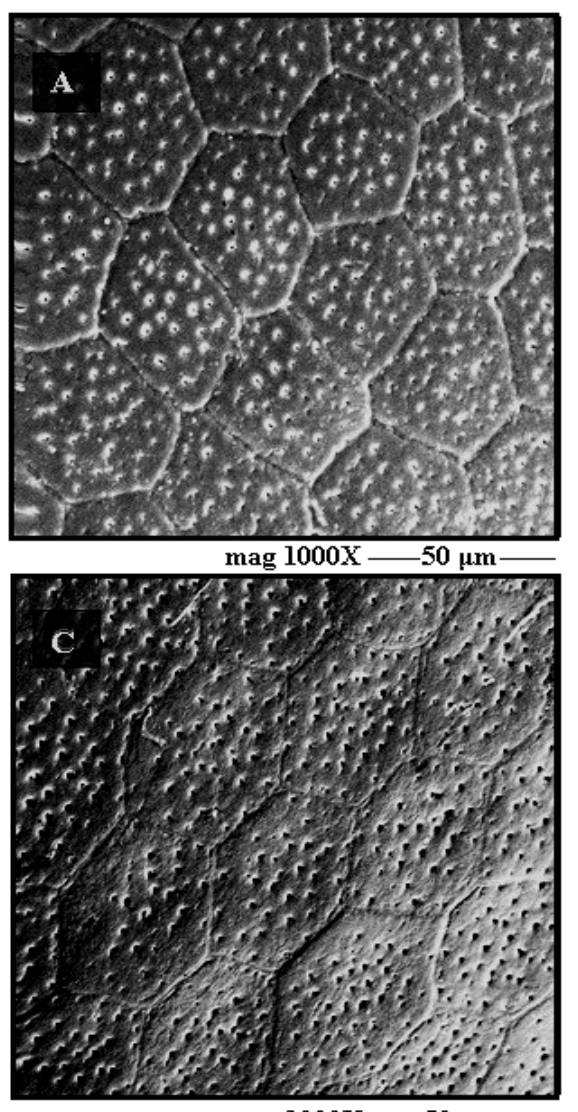

$\operatorname{mag} 1000 \mathrm{X}$
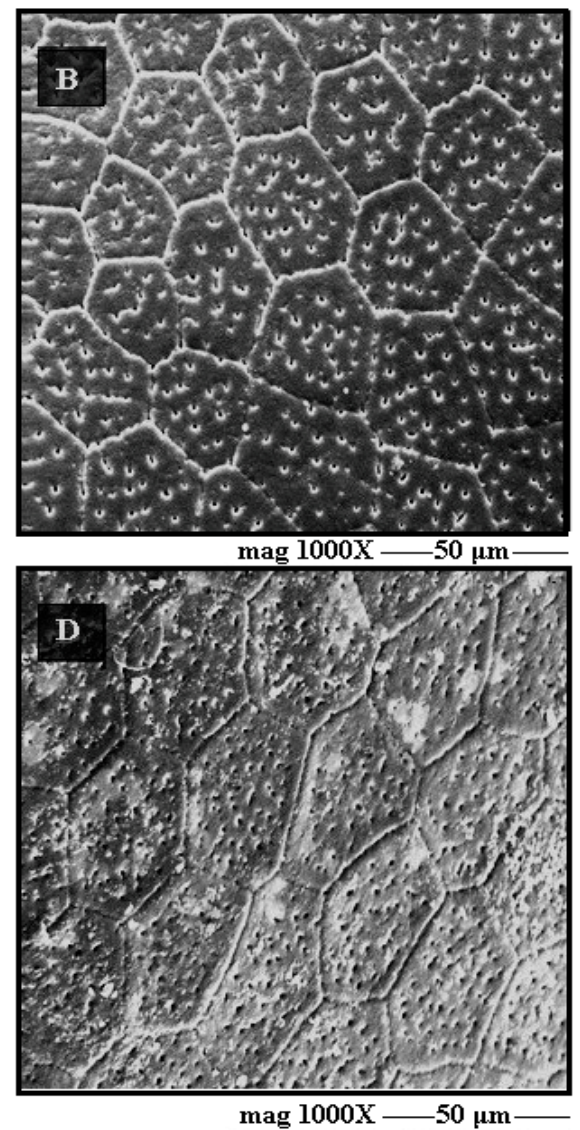

Figure 6. Exochorion detail via scanning electron microscopy (x1000).

(A) T. garciabesi,

(B) T. guasayana, (C) T. patagonica, and (D) T. sordida sensu stricto.

\subsubsection{Histological Analysis of Eggs}

The egg sections of the four species were analyzed using optical microscopy (Figure 7). Photomicrographs make it possible to identify four layers of tissue. The internal tissues: soft endochorion and the stiff endochorion (Figure 7) and the external tissues, the stiff exochorion and the soft exochorion (Figure 7).

Different textures can be observed between the studied tissues: the endochoria of T. garciabesi and T. patagonica (internal part) is smooth (Figure 7A,C), while in T. sordida sensu stricto and T. guasayana is wavy (Figure 7B,D). The profile of the egg exochoria is wavy in the four species, probably because of the hexagonal and pentagonal ornamentation of the exochoria. In the photomicrographs it is possible to perceive the differences in the thickness of the tissues: T. garciabesi and T. patagonica are thin and relationship and T. guasayana and T. sordida sensu stricto thick. There are also differences in the thickness of the stiff exochorion, in guasayana and T. sordida are thick in T. garciabesi and T. patagonica are less apparent.

\subsection{Morphometric Study Morphometry of Eggs}

The two measured parameters show the metric variability between eggs of the four studied species (Figure 8). Regarding the total length of the eggs, T. patagonica presents the largest average size with $1.77 \pm 0.05 \mathrm{~mm}$ followed by T. sordida sensu stricto $1.72 \pm 0.05 \mathrm{~mm}$. T. garciabesi with $1.70 \pm 0.09 \mathrm{~mm}$ and $T$. guasayana $1.61 \pm 0.09 \mathrm{~mm}$ have a lower mean total length of the eggs. T. garciabesi and T. sordida sensu stricto have statistically similar total egg length (Table 2). Therefore, the relation according to the egg length is: T. patagonica $>$ T. sodida sensu stricto $>$ T. garciabesi $>$ T. guasayana (Figure 8). 

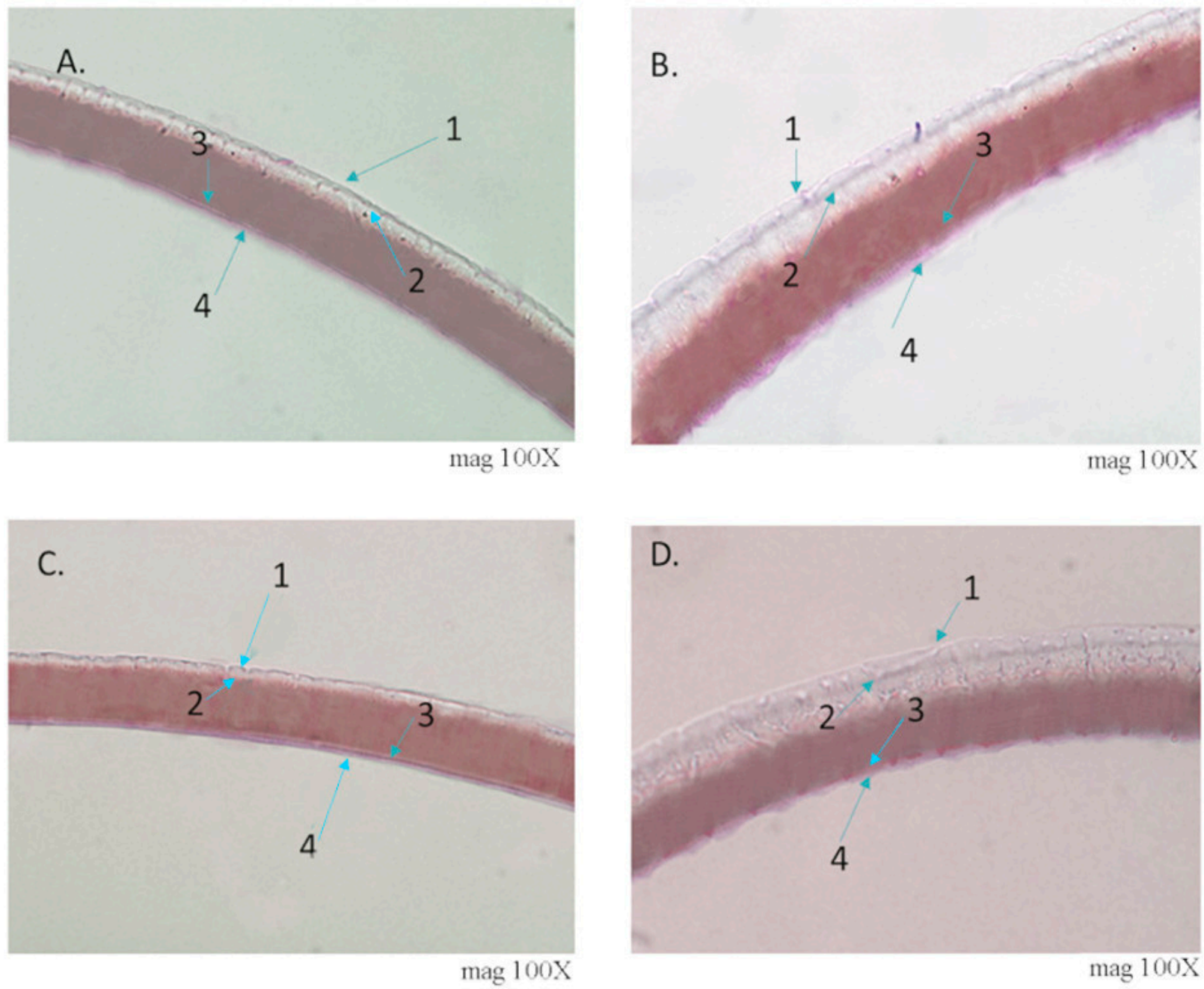

Figure 7. Photomicrographs of sections of eggs chorion stained with Harris' Hematoxylin and Eosin at x100 magnification. (A) T. garciabesi, (B) T. guasayana, (C) T. patagonica, and (D) T. sordida sensu stricto. 1. stiff exochorion, 2 . soft exochorion, 3. stiff endochorion, and 4. soft endochorion.

A.

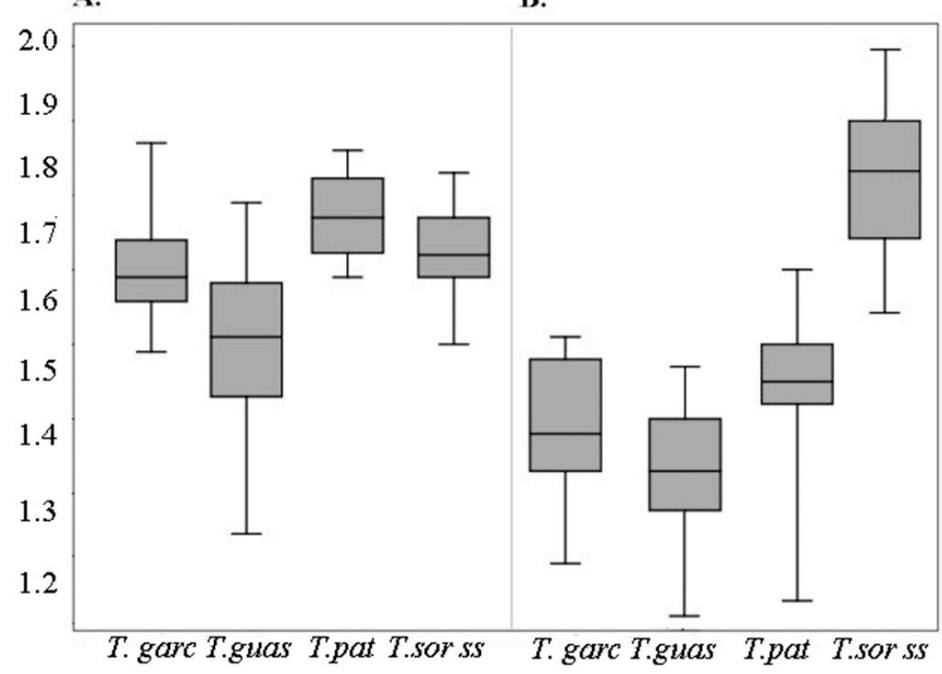

Figure 8. Box plot showing variation of length of eggs (A) and perimeter opening of the operculum (B). T. garciabesi (T. garc), T. guasayana (T. guas), T. patagonica (T. pat), and T. sordida stricto sensu (T. sord ss). 
Table 2. Minimum (Min), maximum (Max), average $(\bar{x})$, and standard deviations (SD) of the length and opening of the perimeter of the operculum of length and opening of the perimeter of the operculum. T. garciabesi, T. guasayana, T. patagonica, and T. sordida sensu stricto.

\begin{tabular}{ccccccccc}
\hline \multirow{2}{*}{ Species } & \multicolumn{4}{c}{ Length } & \multicolumn{4}{c}{$\begin{array}{c}\text { Opening of the Perimeter of the } \\
\text { Operculum }\end{array}$} \\
\cline { 3 - 9 } & Min & Max & $\bar{x}$ & SD & Min & Max & $\bar{x}$ & SD \\
\hline T. garciabesi & 1.59 & 1.87 & 1.70 & 0.06 & 1.29 & 1.61 & 1.47 & 0.10 \\
T. guasayana & 1.33 & 1.79 & 1.60 & 0.09 & 1.19 & 1.57 & 1.42 & 0.08 \\
T. patagonica & 1.69 & 1.86 & 1.77 & 0.05 & 1.65 & 2.03 & 1.55 & 0.07 \\
T. sordida ss & 1.60 & 1.83 & 1.72 & 0.05 & 1.23 & 1.70 & 1.83 & 0.10 \\
\hline
\end{tabular}

The perimeter of the opening of the operculum showed greater capacity to discriminate eggs among the four species. The largest mean size of the perimeter of the opening of the operculum was T. sordida sensu stricto $1.83 \pm 0.10 \mathrm{~mm}$, followed by T. patagonica with 1.5 $5 \pm 0.07 \mathrm{~mm}$, the averages of T. garciabesi and T. patagonica were lower $1.47 \pm 0.10 \mathrm{~mm}$ and $1.42 \pm 0.08 \mathrm{~mm}$, respectively (Table 2). The morphometric relationship of the perimeter opening of the operculum from the largest to the smallest is: T. sordida sensu stricto $>$ T. patagonica $>$ T. garciabesi $>$ T. guasayana.

The variables of length and perimeter of the operculum forma the estimates for the levels of significance. The four species show significant differences between the averages. However, T. garciabesi and T. sordida sensu stricto do not show differences in length averages (Table 3).

Table 3. Results of Turkey's post-hoc test for length (bold) opening of the perimeter of the operculum (italic).

\begin{tabular}{|c|c|c|c|c|}
\hline Species & T. garciabesi & T. guasayana & T. patagonica & T. sordida s.s \\
\hline T. garciabesi & 0.00 & $* * *<0.001$ & $* * *<0.001$ & $* * *<0.001$ \\
\hline T. guasayana & $* * *<0.001$ & 0.00 & $* * *<0.001$ & $* * *<0.001$ \\
\hline T. patagonica & $* * *<0.001$ & $* * *<0.001$ & 0.00 & $* * *<0.001$ \\
\hline T. sordida s.s & $n s$ & $* * *<0.001$ & $*<0.033$ & 0.00 \\
\hline
\end{tabular}

\section{Discussion}

In the subfamily Triatominae, the Triatoma genus currently has the largest number of species, with its complexes and subcomplexes [9] clearly being the most diverse of the subfamily [6]. Discussions about species of Triatoma deserve attention, especially in view of the eco-epidemic scenario in which are inserted [29]. In this study, we present new taxonomic characters for four species of the genus: T. garciabesi, T. guasayana, T. patagonica, and T. sordida sensu stricto, in addition, the female external genitalia and histology of eggs are presented with new diagnostic characters.

Although the recent phylogenies [7] show a distancing of T. guasayana and T. patagonica from $T$. garciabesi and T. sordida sensu stricto, these species have similar morphology and biology, in addition they overlap geographically by several South American regions where they have vectorial potential and consequently deserve attention $[10,11,13]$.

Triatoma garciabesi has been described from specimens captured in central Argentina [30] but synonymized with T. sordida by Lent and Wygodzinsky [17]. Through morphological characters of the head, male genitalia, izoenzymes, and cytogenetics, the species was revalidated in 1998 [13]. In the present study, the results allowed to differentiate T. garciabesi from the other studied species, despite the morphological similarities shared mainly with T. sordida sensu stricto, the results corroborate the revalidation. We demonstrate that it is possible to discriminate the species by the characters of the external female genitalia and by the morphometry of the eggs, however the morphology of the eggs presents similarities that make the diagnosis difficult. 
We demonstrate that it is possible to differentiate the species based on the morphological differences of the female external genitalia evaluated in dorsal, posterior, and ventral view. The dorsal and ventral position has a greater number of characters useful for discriminating these triatomines. In the dorsal position, IX and $X$ have different shapes, being similar in T. garciabesi and T. sordida stricto sensu. In the ventral view, Gc8 are determinants for taxonomy of the studied species. The characterization of the female external genitalia by SEM in Triatominae allows diagnosis at the level of gender [31] and species, in this case assisting in the diagnosis of nearby taxons $[2,25,32]$. The female external genitalia were used in a study with 10 species of the T. brasiliensis subcomplex [9] corroborating the diagnosis of the studied species, in addition to helping in inferring the group's systematic relationships [32].

Eggs of triatomines possess characteristics that are useful in taxonomic studies [27,33]. In this study, the morphological and morphometric data of the eggs proved to be useful to discriminate the four species studied. The results show that the eggs of T. patagonica are the ones that show the greatest morphological and morphometric differences, Triatoma guasayana presents eggs of shorter length when compared to the studied species in addition to morphological differences. Triatoma garciabesi and T. sordida sensu stricto have morphology and morphometric similarities in eggs, however the histological profile is different.

By comparing the results of this study with previous publications, it was possible to determine morphological relationships between the eggs of the species studied with others of Triatoma. The characteristics described for eggs of T. guasayana and T. patagonica allow to show that they present morphological similarities with eggs of species of the T. rubrovaria subcomplex. The results show that the eggs of T. patagonica are the ones that present the greatest morphological and morphometric differences, the elongated profile is similar to the published descriptions for eggs of the species Triatoma rubrovaria (Blan-chard, 1846) and Triatoma klugi Jurbergi, Lent and Galvão, 2001 [34,35]. The approximate average length of the T. guasayana eggs are like those described for Triatoma circummaculata (Stål, 1859) and Triatoma carcavalloi Jurberg, Rocha and Lent, 1998, species of the T. rubrovaria subcomplex [34,36]. It was also possible to show that the morphology of T. sordida sensu stircto eggs is similar to the morphology of T. matogrossensis Leite e Barbosa, 1953; T. vandae Carcavallo et al., 2002 and T. jurbergi Carcavallo, Galvão and Lent, 1998 [36-38]. Triatoma matogrossensis, T. vandae, and T. jurberg $i$ were recently inserted together with the T. sordida subcomplex $[7,8]$.

The proximity of T. guasayana and T. patagonica it was first discussed by Abalos and Wygodzinsky [14] classifying both as allopatric species. Usinger et al. [39] suggest the proximity between T. guasayana and T. patagonica to T. sordida. At present we show that the studied species present morphological and morphometric differences that can corroborate the hypotheses of Pita et al. [8] and Belintani et al. [7].

The evaluation of the eggs exochoria by SEM reveals an ornamentation with homogeneous geometric shapes, a common characteristic of the Triatoma genus as demonstrated by Barata [27]. In Triatomines, eggs have been explored in different approaches and have been shown to be an excellent taxonomic character [34,36-38]. The distinct sublayers of the chorion were first described by Beament [40] used eggs of Rhodnius prolixus Stål, 1859. Beament [40] makes observations about the composition of each layer and the process of formation of the geometric ornamentation present in the chorion. Barata [33] reiterate the histological descriptions by observing eggshells of ten Rhodnius Stål, 1859 species. Recently, the technique was used by Obara et al. [26] where it was possible to characterize the histological profile of eggs of six species of the Triatoma. In this study, it was possible to characterize the histological sections of the chorion of eggs of the four species for the first time. The photomicrographs of the histological sections did not allow the structures to be observed in great detail; however, it was possible to observe important characteristics, such as the four layers that form the egg chorion and their differences. 


\section{Conclusions}

Bearing in mind that the four species studied are important for the current scenario of Chagas disease in South America, this study shows that the morphology and especially the morphometry of eggs are useful characters for differentiation between the studied species. Moreover, the female external genitalia by SEM are useful for taxonomy of these triatomines, especially visualized in the dorsal and ventral position. Finally, useful characters for the diagnosis and specific discrimination between T.garciabesi, T. guasayana, T. patagonica and T. sordida sensu stricto are presented, in addition, relevant systematic information is presented, confirming the current classification of these species.

Author Contributions: T.B. and J.A.d.R. were responsible for conceptualizing. T.B., J.O., J.D.N., K.C.C.A., H.P. were responsible for acquisition and interpretation of results. T.B. was responsible for the investigation, formal analysis, statistical analysis, investigation, data curation, writing of the original draft. J.A.d.R. was responsible for the morphological descriptions, the acquisition of funds, and the writing of the text. E.S.-C. was responsible for the histological study and review of the descriptions. C.G. was responsible for the studied specimens, text review, writing. All authors contributed to the discussion and interpretation of data, revised the manuscript, and approved the submitted version. All authors have read and agreed to the published version of the manuscript.

Funding: This work was supported in part by Coordenação de Aperfeiçoamento de Pessoal de Nível Superior-Brasil (CAPES)—Finance Code 001 (www.capes.gov.br (accessed on 1 January 2021), Research project AUXPE N. 23038.005285 / 2011-12 (JAR). Fundação de Amparo à Pesquisa do Estado de São Paulo (FAPESP) (Process number 2017/05015-7), Conselho Nacional de Desenvolvimento Científico e Tecnológico (CNPq, http:/ / cnpq.br / (accessed on 1 January 2021)) supplying scholarship to TB, by CAPES $\backslash$ Program of Academic Excellence (Proex).

Institutional Review Board Statement: Not applicable.

Acknowledgments: The authors thank the Faculty of Pharmaceutical Sciences and the Graduate Program in Bioscience and Applied Biotechnology at the Pharmacy of the State University of São Paulo (Unesp), Campus of Araraquara. The authors would like to thank the collaborators of the Faculty of Pharmaceutical Sciences parasitology laboratory of the State University of São Paulo (Unesp), especially Lucas Abrantes da Silva and Vinicius Paiva Fernandes. The authors thank Pedro Sérgio Simões from Department of Morphology of Dental School (Unesp). The second author J.O. thanks Eduardo Oyama for the support of collection management and Jucimar Vaz for his support of him in the field in the municipality of Seabra-Bahia—Brazil.

Conflicts of Interest: The authors declare no competing interests.

\section{References}

1. Galvão, C. Taxonomia dos Vetores da Doença de Chagas da Forma à Molécula, quase três séculos de história. In Atualidades em Medicina Tropical no Brasil Vetores: Vetores, 1st ed.; Oliveira, J., Chaboli, K., Aranha, L., Meneguetti, D., Eds.; Stricto Sensu: Rio Branco, Brazil, 2020; Volume 1, pp. 9-37. Available online: https://sseditora.com.br/ebooks/atualidades-em-medicina-tropicalno-brasil-vetores (accessed on 10 October 2020).

2. Zhao, Y.; Galvão, C.; Cai, W. Rhodnius micki, a new species of Triatominae (Hemiptera, Reduviidae) from Bolivia. ZooKeys 2021, 1012, 71-93. [CrossRef] [PubMed]

3. Alevi, K.C.C.; Oliveira, J.; Garcia, A.C.C.; Cristal, D.C.; Delgado, L.M.G.; Bittinelli, I.F.; Reis, Y.V.; Ravazi, A.; Oliveira, A.B.B.; Galvão, C.; et al. Triatoma rosai sp. nov. (Hemiptera, Triatominae): A New Species of Argentinian Chagas Disease Vector Described Based on IntegrativeTaxonomy. Insects 2020, 11, 830. [CrossRef] [PubMed]

4. Monteiro, F.A.; Weirauch, C.; Felix, M.; Lazoski, C.; Abad-Franch, F. Evolution, Systematics, and Biogeography of the Triatominae, Vectors of Chagas Disease. In Advances in Parasitology; Elsevier: Amsterdam, The Netherlands, 2018; Volume 99, pp. 265-344.

5. Justi, S.A.; Galvão, C. The Evolutionary Origin of Diversity in Chagas Disease Vectors. Trends Parasit 2016, 33, 42-52. [CrossRef]

6. Justi, S.A.; Russo, C.A.M.; Mallet, J.R.D.S.; Obara, M.T.; Galvão, C. Molecular phylogeny of Triatomini (Hemiptera: Reduviidae: Triatominae). Parasites Vectors 2014, 7, 149. [CrossRef]

7. Belintani, T.; Oliveira, J.; Pinotti, H.; Silva, L.A.; Alevi, K.C.C.; Galvão, C.; Da Rosa, J.A. Phylogenetic and phenotypic relationships of the Triatoma sordida subcomplex (Hemiptera: Reduviidae: Triatominae). Acta Trop. 2020, 212, 105679. [CrossRef]

8. Pita, S.; Lorite, P.; Nattero, J.; Galvão, C.; Alevi, K.C.; Teves, S.C.; Azeredo-Oliveira, M.T.; Panzera, F. New arrangements on several species subcomplexes of Triatoma genus based on the chromosomal position of ribosomal genes (Hemiptera-Triatominae). Infect. Genet. Evol. 2016, 43, 225-231. [CrossRef] 
9. Schofield, C.; Galvão, C. Classification, evolution, and species groups within the Triatominae. Acta Trop. 2009, 110, 88-100. [CrossRef] [PubMed]

10. Noireau, F.; Gutierrez, T.; Zegarra, M.; Flores, R.; Brenière, F.; Cardozo, L. Cryptic speciation in the Triatoma sordida (Hemiptera: Reduviidae) of Chaco Boliviano. Trop. Med. Int. Health 2014, 3, 364-372. [CrossRef]

11. Panzera, F.; Pita, S.; Nattero, J.; Panzera, Y.; Galvão, C.; Chavez, T.; De Arias, A.R.; Téllez, L.C.; Noireau, F. Cryptic speciation in the Triatoma sordida subcomplex (Hemiptera, Reduviidae) revealed by chromosomal markers. Parasites Vectors 2015, 8, 1-10. [CrossRef]

12. Wisnivesky-Colli, C.; Vezzani, D.; Pietrokovsky, S.M.; Scurti, H.; Iriarte, J. Ecological characteristics of Triatoma patagonica at the southern limit of its distribution (Chubut, Argentina). Memórias Instituto Oswaldo Cruz 2003, 98, 1077-1081. [CrossRef] [PubMed]

13. Jurberg, J.; Galvão, C.; Lent, H.; Monteiro, F.; Lopes, M.C.; Panzera, F.; Pérez, R. Revalidaçtion of Triatoma garciabesi Carcavallo, Cichero, Martínez, Prozen and Ronderos, 1967 (Hemiptera, Reduviidae). Entom. Vectors 1998, 5, 107-122.

14. Abalos, J.W.; Wygodginsky, P. Las Triatominae Argentinas (Reduviidae, Hemiptera). Publ. Inst. Med. Reg. 1951, 601, 1-179.

15. Gorla, D.E.; Jurberg, J.; Catalá, S.S.; Schofield, C.J. Systematics of Triatoma sordida, T. guasayana and T. patagonica (Hemiptera, Reduviidae). Memórias Instituto Oswaldo Cruz 1993, 88, 379-385. [CrossRef] [PubMed]

16. Nattero, J.; Piccinali, R.V.; Lopes, C.M.; Hernández, M.L.; Abrahan, L.; Lobbia, P.A.; Rodríguez, C.S.; De La Fuente, A.L.C. Morphometric variability among the species of the Sordida subcomplex (Hemiptera: Reduviidae: Triatominae): Evidence for differentiation across the distribution range of Triatoma sordida. Parasites Vectors 2017, 10, 412. [CrossRef]

17. Lent, H.; Wygodzinsky, P. Revision of the Triatominae (Hemiptera: Reduviidae) and their significance as vectors of Chagas disease. Bull Am. Mus. Nat. Hist. 1979, 163, 123-520.

18. Hypsa, V.; Tietz, D.F.; Zrzavý, J.; Rego, R.O.M.; Galvao, C.; Jurberg, J. Phylogeny and biogeography of Triatominae (Hemiptera: Reduviidae): Molecular evidence of a New World origin of the Asiatic clade. Mol. Phylogenetics Evol. 2002, 23, 447-457. [CrossRef]

19. García, B.A.; Moriyama, E.N.; Powell, J.R. Mitochondrial DNA sequences of triatomines (Hemiptera: Reduviidae): Phylogenetic relationships. J. Med Èntomol. 2001, 38, 675-683. [CrossRef]

20. Forattini, O.P. Biogeography, origin, and distribution of Triatominae domicile dispersal in Brazil. Revista Saude Publica 1980, 14, 265-299. [CrossRef]

21. Actis, A.S.; Traversa, O.C.; Carcavallo, R.U. Estudios taxonómicos sobre el género Triatoma mediante la electroforesis de la linfa. An. Esc. Nac. C Biol. 1965, 13, 97-106.

22. Gonzalez-Britez, N.E.; Carrasco, H.J.; Purroy, C.E.M.; Feliciangeli, M.D.; Emaldonado, M.; Lopez, E.; Segovia, M.J.; De Arias, A.E. Genetic and Morphometric Variability of Triatoma sordida (Hemiptera: Reduviidae) from the Eastern and Western Regions of Paraguay. Front. Public Health 2014, 2, 149. [CrossRef]

23. Madeira, F.F.; Dos Reis, Y.V.; Bittinelli, I.D.F.; Delgado, L.M.G.; De Oliveira, J.; Mendonça, V.J.; Moreira, F.F.F.; De AzeredoOliveira, M.T.V.; Da Rosa, J.A.; Alevi, K.C.C. Genetic Structure of Brazilian Populations of Triatoma sordida (Stål, 1859) (Hemiptera, Triatominae) by Means of Chromosomal Markers. Am. J. Trop. Med. Hyg. 2019, 100, 907-910. [CrossRef] [PubMed]

24. Madeira, F.F.; Dlgado, L.M.G.; Bittinelli, I.F.; Sartori, R.Q.; Oliveira, J.; Rosa, J.A.; Azeredo-Oliveira, M.T.V.; Alevi, K.C.C. Revisiting the genetic variability of Brazilian peridomestic populations of the Chagas disease vector Triatoma sordida (Stål 1859) (Hemiptera, Triatominae). Infect. Genet. Evol. 2020, 85, 104568. [CrossRef] [PubMed]

25. Da Rosa, J.A.; Mendonça, V.J.; Gardim, S.; De Carvalho, D.B.; De Oliveira, J.; Nascimento, J.D.; Pinotti, H.; Pinto, M.C.; Cilense, M.; Galvão, C.; et al. Study of the external female genitalia of 14 Rhodnius species (Hemiptera, Reduviidae, Triatominae) using scanning electron microscopy. Parasites Vectors 2014, 7, 17. [CrossRef] [PubMed]

26. Obara, M.T.; Da Rosa, J.A.; Silva, N.N.; Ceretti, W.; Urbinatti, P.R.; Barata, J.M.S.; Jurberg, J.; Galvão, C. Morphological and histological study of eggs of six species of the Triatoma genus (Hemiptera: Reduviidae). Neotrop. Entomol. 2007, 36, 798-806. [CrossRef]

27. Barata, J.M.S. Aspectos morfológicos de ovos de Triatominae II-Características macroscópicas e exocoriais de dez espécies do gênero Rhodnius Stal, 1859 Hemiptera, Reduviidae). Rev. Bra. Entomol. 1981, 24, 490-542. [CrossRef] [PubMed]

28. Rosa, J.A.; Hernany, H.G.; Barata, J.M.S. Diferença no tamanho de cascas de ovos de colônias de Panstrongylus megistus. Revista de Saúde Pública 2003, 37, 528-530. [CrossRef]

29. Lidane, K.C.F.; Andrade, F.A.; Bavia, L.; Damasceno, F.S.; Beltrame, M.G.; Messias-Reason, J.A.; Sandri, T.L. Chagas Disease: From Discovers to a Worldwide Health Problem. Front. Public Health 2019, 7, 166. [CrossRef]

30. Carcavallo, R.U.; Cichero, J.A.; Martínez, A.; Prosen, A.E.; Ronderos, R. Una Nueva Especie del Género Triatoma Laporte (Hemiptera, Reduviidae, Triatominae). Segundas Jornadas Entomoepidemiologicas Argertinas 1967, 2, $43-48$.

31. Da Rosa, J.A.; Mendonça, V.J.; Rocha, C.S.; Gardim, S.; Cilense, M. Characterization of the external female genitalia of six species of Triatominae (Hemiptera: Reduviidade) by scanning electron microscopy. Memórias Instituto Oswaldo Cruz 2010, 105, $286-292$. [CrossRef]

32. Oliveira, J.; Chaboli, K.C.C.; Almeida, C.E.; Mendonça, V.J.; Costa, J.; Rosa, J.A. Triatoma brasiliensis species complex: Characterization of the external female genitalia. J. Vect. Ecol. 2020, 45, 57-68. [CrossRef]

33. Barata, J.M.S. Macroscopic and Exocorial Structures of Triatominae Eggs (Hemiptera, Reduviidae). In Atlas of Chagas Disease Vectors in the Americas; Carcavallo, R.U., Galíndez-Girón, I., Jurberg, J., Lent, H., Eds.; Fiocruz: Rio de Janeiro, Brazil, 1998; pp. 409-448. 
34. Rosa, J.A.; Barata, J.M.S.; Santos, J.L.; Cilense, M. Egg morphology of Triatoma circummaculata and Triatoma rubrovaria (Hemiptera, Reduviidae). Revista Saúde Pública 2000, 34, 5. [CrossRef] [PubMed]

35. Jurberg, J.; Barbosa, H.S.; Galvão, C.; Rocha, D.S.; Silva, M.B. Description of eggs and nymphs from Triatoma klugi. Iheringia Série Zoologia 2010, 100, 43-54. [CrossRef]

36. Jurberg, J.; Galvão, C.; Santos, C.M.; Rangel, M.A.A. Description of eggs and nymphs of Triatoma carcavalloi through optical microscopy. Iheringia Série Zoologia 2008, 98, 4.

37. Jurberg, J.; Silva, M.B.A.; Galvão, C.; Rocha, D.S.; Barbosa, H.B.; Carcavallo, R.U. Description of Eggs and Nymphal Stadiums of Triatoma jurbergi Carcavallo, Galvão \& Lent, 1998 Seen Through Microscopy Optics and Scanning Electronics (Hemiptera, Reduviidae). Memórias Instituto Oswaldo Cruz 2002, 97, 209-216.

38. Silva, M.B.A.; Jurberg, J.; Barbasa, H.S.; Rocha, D.S.; Carcavallo, R.U.; Galvão, C. Comparative morphology of eggs and nymphs of Triatoma vandae Carcavallo, Jurberg, Rocha, Galvão, Noireau \& Lent, 2002 and Triatoma williami Galvão, Souza \& Lima, 1965. Memórias Instituto Oswaldo Cruz 2005, 100, 549-561.

39. Usinger, R.L.; Wygodzinsky, P.; Ryckman, R.E. The Biosystematics of Triatominae. Annu. Rev. Entomol. 1966, 11, 309-330. [CrossRef]

40. Beament, J.W.L. The formation and structure of the chorion of the egg in an hemipteran, Rhodnius prolixus. J. Cell. Sci. 1946, 87, 393-439. 